\title{
IMPACT OF GOODS AND SERVICES TAX (GST) ON CUSTOMERS' PERCEPTION IN ODISHA: AN EMPIRICAL STUDY
}

\author{
Dr. Sanjeeb Kumar Dey* \\ Principal Investigator, OURIIP Seed Fund Research Project, Assistant Professor in \\ Commerce, Department of Commerce, Ravenshaw University, Odisha, India \\ Dr. Ch. Sudipta Kishore Nanda and Dr. Madhumala Pathy \\ Assistant Professor in Commerce, Department of Commerce, \\ Ravenshaw University, Odisha, India \\ *Corresponding Author
}

\begin{abstract}
Goods and Services tax is one of revolutionary tax reforms in India applicable from July 2017. The basic aim of this reform is to remove all cascading effects and to bring uniformity in tax and market throughout the nation. During this three years of its implementation, it has been amended number of times to make it simpler and user friendly. Customers are the major stakeholder of this reforms and the success of this new tax laws depends upon the acceptance by them in right prospective including others. In this paper, an attempted has been made to study the impact of goods and services tax on customers' perception in Odisha state. Structure questionnaires have been used to collect responses covering different districts of Odisha. It is concluded that more than 95\% of customers are at least know something about GST and customers education, profession and place play a dominant role in deciding the perception of customers towards prices, expenditure and consumptions after implementation of GST.
\end{abstract}

Key words: Goods and Services Tax, Costumers' Perception, Odisha, Awareness.

Cite this Article: Sanjeeb Kumar Dey, Ch. Sudipta Kishore Nanda and Madhumala Pathy , Impact of Goods and Services Tax (GST) on Customers' Perception in Odisha: An Empirical Study, International Journal of Management, 11(12), 2020, pp.669-678. http://iaeme.com/Home/issue/IJM?Volume=11\&Issue=12

\section{INTRODUCTION}

The tax constitutes a major source of revenue for Government exchequer which may be direct or indirect tax. Indirect taxes are basically levied on consumption, sales and services. There were more than 27 types of indirect taxes in India till July 2017. The introduction of goods 
and services tax (GST) from 1st July 2017 is one of the biggest indirect tax reforms undertaken since our independence to promote commerce and industry (Garg \& Kumar 2017, Kawale \& Aher 2017, Patil 2017, Tiwari \& Singh 2018). The basic foundation of introducing GST is to remove the cascading effects of taxation and simplification of tax law compliance (Beri 2017, Leena \& Sameena 2017, Nayyar \& Singh 2018). Since its implementation, number of modifications have been undertaken to make it simpler and user friendly. It took almost 13 years to implement this new law after its inception. The implementation of GST would be successful if it is adopted by different stakeholders in its true spirit (Antony and John, 2020). Different people have different views and opinions about the rules, regulations and procedures of GST. It creates confusion among the manufacturers, sellers, consumers, practitioners, etc. Now an important questions arises i.e. how is it perceived by customers? or what is there level of awareness or understanding about GST? With this background, attempt has been made to assess level of awareness and perceptions of customers in Odisha.

\section{LITERATURE REVIEW}

Das (2017) has compared various GST rates in the country and evaluated the benefits related to the GST. Mahendra (2017) studied the effeteness on different types of manufacturing goods and services under the GST regime. He found that the cement industry, automobile industry can enjoy operating \& transportation expenses while the telecom and banking \& financial services will have negative scenario. Verma (2017) concluded that the five tire structure of GST has kept away from the 'one nation one tax nation' because different tax slabs are used for different products. Introduction of goods and services a tax has affected adversely the investors and brokers of stock market in India as it increases the cost of transactions and compliance by charging higher surcharge then earlier (Joy et al. 2020). Similar findings has been witnessed in case of customer's perception towards goods and services tax in Ernakulum district (Vincent \& MR, 2020). Since its implementation, customers and retailers were not remarkably aware and concuss about the provisions and procedures of goods and services tax in Kanniyakumari district (Dhanuja 2020), in Coimbatore (Dillip et al. 2018) and in Delhi NCR (Gupta \& Agarwal 2017). Students' community being an important stakeholders of implementation of GST in Malaysia had limited knowledge or awareness and Government should create more awareness about it (Shaari et al. 2015, Muthupandi et al. 2017). Similarly, public acceptance and compliance of new tax depends on tax payer's knowledge of taxation, moral value, social norms, and trust in legal and political system, simplicity and transparency of tax as concluded by Ling et al. 2016. Gupta \& Agarwal 2017 found no significant correlation between new indirect tax structure and spending pattern of Indian consumers. Similar result was also witnessed by Carvalho and Lian (2010) in customers spending and expenditure pattern of Canada. Parbeja (2017) arrived at a conclusion that people are accepting GST with an anticipation of benefits for common men after performing a sentiment analysis from twitter data. Sreekumar \& Chithra (2018) found that around 3/4th of the respondents were aware about GST from their friends/ family and viewed GST will be beneficial to the customers.

\section{OBJECTIVES OF THE STUDY}

Though numbers of research have been done during these forty months. Most of the papers are theoretical and overall opinion based on secondary data or media output. Hardly any work has been conducted in Odisha context. The primary objective of this study is to:

- Evaluate the level of awareness about GST among the Customers in Odisha 
- Identify their perceptions about price, expenditure and consumption in GST regime.

\section{METHODOLOGY}

The present study is both analytical and empirical in nature. The sample domain for the study is Odisha state. On the basis of responses we have categorised the sample under four major cities i.e. Cuttack, Barhampur and Sambalpur and others. The sample size is 450 respondents covering these cities. Random sampling method is used to collect data through a structured close ended questionnaire in the month of August and September of 2020. Out of 450 respondents, only 401 respondents are found to be filled up all aspect completely and hence our sample for all practical purpose is 401 . In the courses of analysis, various statistical tools like Mean, Co-efficient of variation, and Chi-square, etc. have been used to attain the desired objectives. We have used statistical software packages like SPSS, Excel for all analysis of data. After going through an exhaustive study of related literatures and on the basis of objectives of the study, the following hypothesis have been formulated

- There is no association between perception about price, expenditure, consumption in GST ear and Customers demographic profile.

\section{RESULTS AND DISCUSSION}

\subsection{Reliability Test}

To test consistency of the responses, we have used Cronbach's alpha reliability test and the results are appended in table-1 and table-2. The cronbach's Alpha value is 0.905 which indicates a high level of consistency for the scale with this questionnaires. Further the variance of responses is also very low i.e. 0.009 of the total 15 questions.

Table 1 Reliability Statistics

\begin{tabular}{|r|r|r|}
\hline Cronbach's Alpha & \multicolumn{2}{|c|}{$\begin{array}{c}\text { Cronbach's Alpha Based on } \\
\text { Standardized Items }\end{array}$} \\
\hline 0.905 & 0.906 & N of Items \\
\hline
\end{tabular}

Source: Authors calculations

Table 2 Summary Item Statistics

\begin{tabular}{|l|r|r|r|r|r|r|r|}
\hline & Mean & Minimum & Maximum & Range & $\begin{array}{l}\text { Maximum } / \\
\text { Minimum }\end{array}$ & Variance & \multicolumn{1}{c|}{$\begin{array}{c}\text { N of } \\
\text { Items }\end{array}$} \\
\hline $\begin{array}{l}\text { Inter-Item } \\
\text { Correlations }\end{array}$ & .392 & .192 & .588 & .396 & 3.060 & .009 & 15 \\
\hline
\end{tabular}

Source: Authors calculations

\subsection{Descriptive Statistics}

Table-3 provides a descriptive profile of the sample considered in this study. Total 401 respondents have been categorised with various demographic variables. Out of total respondents, $54.4 \%$ represents male while the rest are female. Majority of the respondents i.e. $90 \%$ of the sample belongs to the age group of 18-30 while the rest are above 30 years. So far education is concerned, $62.60 \%$ is from the matriculation to graduation level and $36.90 \%$ belongs to above graduation level. The reason behind such type of responses is upper age group and below matriculation customers express their unwillingness to participate in this survey. Similarly $75.1 \%$ of total respondents are students, $13.2 \%$ are service holders and $9.5 \%$ 
Impact of Goods and Services Tax (GST) on Customers' Perception in Odisha: An Empirical Study

represents business and profession. $72.3 \%$ responses are from the retail customers those who purchases for own domestic consumptions and rest are institutional customers.

Table 3 Sample Profile

\begin{tabular}{|c|c|c|c|}
\hline Category & Demographic Profile & No. of Respondents & Percentage \\
\hline \multirow[t]{2}{*}{ Gender } & Male & 218 & 54.4 \\
\hline & Female & 183 & 45.6 \\
\hline \multirow[t]{4}{*}{ Age } & $18-30$ & 361 & 90.0 \\
\hline & $31-45$ & 33 & 8.20 \\
\hline & $46-60$ & 4 & 1.00 \\
\hline & Above 60 & 3 & 0.80 \\
\hline \multirow{3}{*}{$\begin{array}{c}\text { Educational } \\
\text { Qualification }\end{array}$} & Below Matriculation & 2 & 0.50 \\
\hline & $10^{\text {th }}$ to Graduation & 251 & 62.60 \\
\hline & Above Graduation & 148 & 36.90 \\
\hline \multirow{5}{*}{ Profession } & Housewife & 9 & 2.20 \\
\hline & Students & 301 & 75.10 \\
\hline & Service Holders & 53 & 13.2 \\
\hline & $\begin{array}{l}\text { Self } \\
\text { Employed/Business }\end{array}$ & 12 & 3.00 \\
\hline & Professional & 26 & 6.50 \\
\hline \multirow{4}{*}{$\begin{array}{l}\text { Geographical } \\
\text { Location }\end{array}$} & Cuttack/Bhubaneswar & 220 & 54.90 \\
\hline & Berhampur & 23 & 5.70 \\
\hline & Sambalpur & 16 & 4.00 \\
\hline & Other & 142 & 35.40 \\
\hline \multirow[t]{2}{*}{ Type of Customers } & Retail & 290 & 72.30 \\
\hline & Institutional & 111 & 27.70 \\
\hline Total & & 401 & 100.00 \\
\hline
\end{tabular}

Source: Authors calculations

\subsection{Assessment of Customers Opinion}

Table 4 Responses on Common Idea on GST

\begin{tabular}{|c|r|r|r|}
\hline Responses & Frequency & Percent & Cumulative Percent \\
\hline YES & 391 & 97.5 & 97.5 \\
NO & 10 & 2.5 & 100.0 \\
Total & 401 & 100.0 & \\
\hline
\end{tabular}

Source: Authors calculations

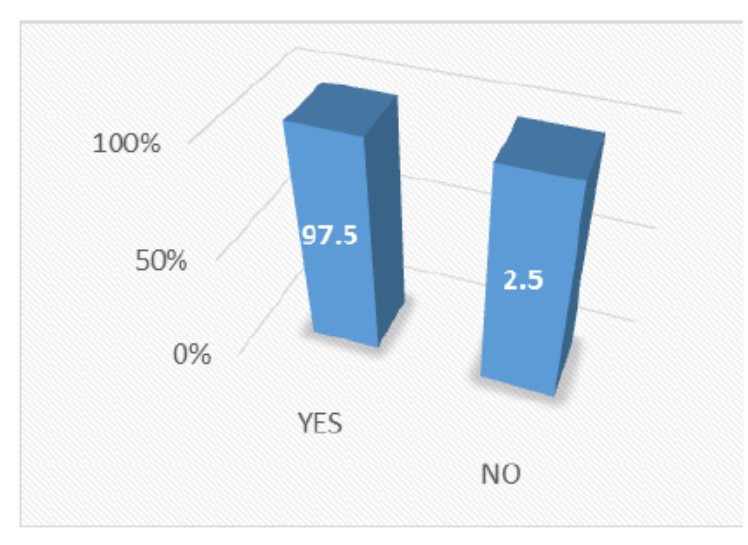

Figure 1 Responses on Common Idea on GST 


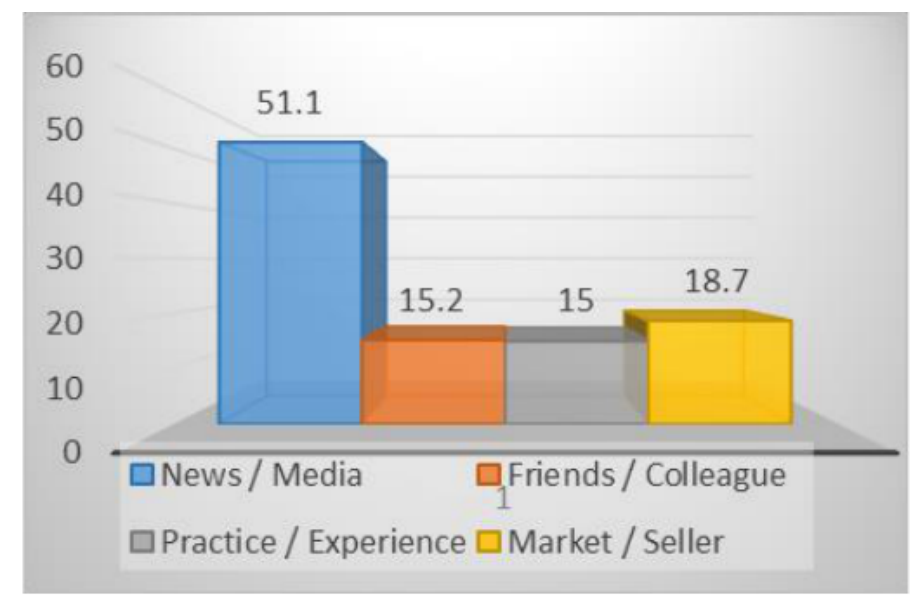

Figure 2 Mode of getting Common Idea on GST

Table- 4 and figure -1 indicates about $97.5 \%$ of the respondents have a common idea about goods and services taxes that is being implemented since 2017.

Table 5 Mode of getting idea about GST

\begin{tabular}{|l|r|r|r|}
\hline & Frequency & Percent & Cumulative Percent \\
\hline News / Media & 205 & 51.1 & 51.1 \\
Friends / Colleague & 61 & 15.2 & 66.3 \\
Practice / Experience & 60 & 15.0 & 81.3 \\
Market / Seller & 75 & 18.7 & 100.0 \\
Total & 401 & 100.0 & \\
\hline
\end{tabular}

Source: Authors calculations

Table -5 and figure- 2 explores the mode of obtaining the awareness of goods and services tax by the respondents. About 51.1\% know from news and media and around 15\% from friends and colleagues, practices and market or sellers each. So it is prominent that news and media plays an important role in making customers aware about GST.

Table- 6 shows that $42 \%$ of respondents have opinion GST has increased the prices of majority of commodities while $46 \%$ viewed prices of selected goods have increased after GST. Regarding prices of services, table- 7 clearly indicates that $45 \%$ of sample agreed on increase of prices of service during GST regime. $51 \%$ of the respondents agreed on fact that the GST has increased their expenditure whereas 15\% agreed on decrease and $20 \%$ agreed on no change in expenditure (table-8). So far consumption is concerned, 50\% of respondents viewed no change while $25 \%$ viewed increase in consumption after GST (table-9).

\subsection{Testing of Hypothesis}

Null Hypothesis-1: There is no association between perception of customers about increase in price of goods after GST implementation and their demographic profile.

To test this assumption, we have applied chi-square test and results are shown in table-6. From the table it is clear that p-value with respect to educational qualification $(0.003)$, location (0.012) and type of customers (0.007) are less than 0.05 at $5 \%$ level of significance and hence null hypothesis is rejected. We may conclude that opinion of customers about increase of prices of goods after implementation of GST is closely associated with educational qualification, cities or location and types of customers. While for other demographic aspects i.e. gender, age and profession, the p-value is more than 0.05 which indicates no association with their opinion. 
Impact of Goods and Services Tax (GST) on Customers' Perception in Odisha: An Empirical Study

Table 6 Perception of Customers about increase of prices of goods after GST

\begin{tabular}{|c|c|c|c|c|c|c|}
\hline Gender & Yes & No & In Selected Goods & No Idea & $\chi^{2}$ & P-Value \\
\hline Male & 85 & 25 & 98 & 10 & \multirow[t]{2}{*}{5.392} & \multirow[t]{2}{*}{0.145} \\
\hline Female & 82 & 10 & 85 & 6 & & \\
\hline \multicolumn{7}{|l|}{ Age group } \\
\hline $18-30$ & 151 & 30 & 168 & 12 & \multirow[t]{4}{*}{9.641} & \multirow[t]{4}{*}{0.380} \\
\hline $31-45$ & 13 & 4 & 12 & 4 & & \\
\hline $46-60$ & 2 & 1 & 1 & 0 & & \\
\hline $61 \&$ above & 1 & 0 & 2 & 0 & & \\
\hline \multicolumn{7}{|l|}{ Educational Qualification } \\
\hline up to 10 th & 1 & 0 & 0 & 1 & \multirow[t]{3}{*}{19.485} & \multirow[t]{3}{*}{0.003} \\
\hline 10th to graduation & 117 & 19 & 105 & 10 & & \\
\hline above graduation & 49 & 16 & 78 & 5 & & \\
\hline \multicolumn{7}{|l|}{ Profession } \\
\hline House wife & 4 & 1 & 2 & 2 & \multirow[t]{5}{*}{15.280} & \multirow[t]{5}{*}{0.226} \\
\hline Student & 127 & 25 & 141 & 8 & & \\
\hline Service holder & 24 & 4 & 22 & 3 & & \\
\hline Self employed / business & 5 & 1 & 5 & 1 & & \\
\hline Profession & 7 & 4 & 13 & 2 & & \\
\hline \multicolumn{7}{|l|}{ Geographical Location } \\
\hline Cuttack / Bhubaneswar & 88 & 15 & 113 & 4 & \multirow[t]{4}{*}{21.056} & \multirow[t]{4}{*}{0.012} \\
\hline Berhampur & 13 & 1 & 6 & 3 & & \\
\hline Sambalpur & 6 & 3 & 5 & 2 & & \\
\hline Other & 60 & 16 & 59 & 7 & & \\
\hline \multicolumn{7}{|l|}{ Type of Customer } \\
\hline Retail & 114 & 19 & 143 & 14 & \multirow[t]{2}{*}{12.000} & \multirow[t]{2}{*}{0.007} \\
\hline Institutional & 53 & 16 & 40 & 2 & & \\
\hline
\end{tabular}

Source: Authors calculations

Null Hypothesis-2: There is no association between perception of customers about increase in price of services after GST implementation and their demographic profile.

To test this assumption, we have applied chi-square test and results are shown in table-7. From the table it is clear that p-value with respect to profession $(0.005)$, location $(0.022)$ and type of customers $(0.001)$ are less than 0.05 at $5 \%$ level of significance and hence null hypothesis is rejected. We may conclude that opinion of customers about increase of prices of services after implementation of GST is closely associated with profession, cities or location and types of customers. While for other demographic aspect i.e. gender, age and educational qualification, the p-value is more than 0.05 which indicates no association with their opinion.

Table-7: Perception of Customers towards GST increased the prices of Services

\begin{tabular}{|c|c|c|c|c|c|c|}
\hline Gender & Yes & No & In Selected Services & No Idea & $x^{2}$ & P-Value \\
\hline Male & 106 & 31 & 71 & 10 & \multirow[t]{2}{*}{6.354} & \multirow[t]{2}{*}{0.096} \\
\hline Female & 84 & 20 & 59 & 20 & & \\
\hline \multicolumn{7}{|l|}{ Age group } \\
\hline $18-30$ & 173 & 47 & 117 & 24 & \multirow[t]{4}{*}{8.879} & \multirow{4}{*}{0.448} \\
\hline $31-45$ & 14 & 3 & 12 & 4 & & \\
\hline $46-60$ & 1 & 1 & 1 & 1 & & \\
\hline $61 \&$ above & 2 & 0 & 0 & 1 & & \\
\hline \multicolumn{7}{|c|}{ Educational Qualification } \\
\hline up to 10 th & 1 & 0 & 0 & 1 & \multirow[t]{3}{*}{10.473} & \multirow[t]{3}{*}{0.106} \\
\hline 10th to graduation & 126 & 34 & 72 & 19 & & \\
\hline above graduation & 63 & 17 & 58 & 10 & & \\
\hline
\end{tabular}


Dr. Sanjeeb Kumar Dey, Dr. Ch. Sudipta Kishore Nanda and Dr. Madhumala Pathy

\begin{tabular}{|c|c|c|c|c|c|c|}
\hline \multicolumn{7}{|l|}{ Profession } \\
\hline House wife & 5 & 0 & 0 & 4 & \multirow{5}{*}{28.457} & \multirow[t]{5}{*}{0.005} \\
\hline Student & 146 & 42 & 95 & 18 & & \\
\hline Service holder & 22 & 5 & 23 & 3 & & \\
\hline Self employed / business & 7 & 1 & 3 & 1 & & \\
\hline Profession & 10 & 3 & 9 & 4 & & \\
\hline \multicolumn{7}{|l|}{ Geographical Location } \\
\hline Cuttack / Bhubaneswar & 104 & 23 & 82 & 11 & \multirow[t]{4}{*}{19.429} & \multirow[t]{4}{*}{0.022} \\
\hline Berhampur & 12 & 0 & 6 & 5 & & \\
\hline Sambalpur & 7 & 3 & 4 & 2 & & \\
\hline Other & 67 & 25 & 38 & 12 & & \\
\hline \multicolumn{7}{|l|}{ Type of Customer } \\
\hline Retail & 143 & 25 & 97 & 25 & \multirow[t]{2}{*}{16.813} & \multirow[t]{2}{*}{0.001} \\
\hline Institutional & 47 & 26 & 33 & 5 & & \\
\hline
\end{tabular}

Source: Authors calculations

Null Hypothesis-3: There is no association between perception of customers about impact of GST on expenditure and their demographic profile.

To test this assumption, we have applied chi-square test and results are shown in table- 8 . From the table it is clear that p-value with respect to profession (0.002), location (0.041) and type of customers $(0.001)$ are less than 0.05 at $5 \%$ level of significance and hence null hypothesis is rejected. We may conclude that opinion of customers about impact of GST is closely associated with profession, cities or location and types of customers. While for other demographic aspect i.e. gender, age and educational qualification, the p-value is more than 0.05 which indicates no association with their opinion.

Table 8 Perception of Customers towards impact of GST on Expenditure

\begin{tabular}{|c|c|c|c|c|c|c|}
\hline Gender & Increase & Decrease & Constant & No idea & $x^{2}$ & P-Value \\
\hline Male & 117 & 32 & 42 & 27 & \multirow{2}{*}{0.571} & \multirow{2}{*}{0.903} \\
\hline Female & 105 & 24 & 33 & 21 & & \\
\hline \multicolumn{7}{|l|}{ Age group } \\
\hline $18-30$ & 200 & 49 & 67 & 45 & \multirow[t]{4}{*}{9.635} & \multirow[t]{4}{*}{0.381} \\
\hline $31-45$ & 19 & 5 & 7 & 2 & & \\
\hline $46-60$ & 2 & 0 & 1 & 1 & & \\
\hline $61 \&$ above & 1 & 2 & 0 & 0 & & \\
\hline \multicolumn{7}{|l|}{ Educational Qualification } \\
\hline up to $10^{\text {th }}$ & 1 & 0 & 0 & 1 & \multirow[t]{3}{*}{8.253} & \multirow[t]{3}{*}{0.220} \\
\hline 10th to graduation & 131 & 35 & 49 & 36 & & \\
\hline above graduation & 90 & 21 & 26 & 11 & & \\
\hline \multicolumn{7}{|l|}{ Profession } \\
\hline House wife & 3 & 0 & 1 & 5 & \multirow[t]{5}{*}{30.671} & \multirow{5}{*}{0.002} \\
\hline Student & 165 & 44 & 58 & 34 & & \\
\hline Service holder & 36 & 6 & 7 & 4 & & \\
\hline Self employed / business & 5 & 0 & 3 & 4 & & \\
\hline Profession & 13 & 6 & 6 & 1 & & \\
\hline \multicolumn{7}{|l|}{ Geographical Location } \\
\hline Cuttack / Bhubaneswar & 129 & 28 & 42 & 21 & \multirow[t]{4}{*}{17.505} & \multirow[t]{4}{*}{0.041} \\
\hline Berhampur & 12 & 1 & 2 & 8 & & \\
\hline Sambalpur & 8 & 4 & 2 & 2 & & \\
\hline Other & 73 & 23 & 29 & 17 & & \\
\hline \multicolumn{7}{|l|}{ Type of Customer } \\
\hline Retail & 158 & 30 & 61 & 41 & \multirow[t]{2}{*}{17.136} & \multirow[t]{2}{*}{0.001} \\
\hline Institutional & 64 & 26 & 14 & 7 & & \\
\hline
\end{tabular}

Source: Authors calculations 
Null Hypothesis-4: There is no association between perception of customers about impact of GST on consumption and their demographic profile.

To test this assumption, we have applied chi-square test and results are shown in table-9. From the table it is clear that p-value with respect to profession $(0.000)$ and type of customers (0.015) are less than 0.05 at 5\% level of significance and hence null hypothesis is rejected. We may conclude that opinion of customers about impact of GST on their consumption is closely associated with profession and types of customers. While for other demographic aspect i.e. gender, age, educational qualification and location, the p-value is more than 0.05 which indicates no association with their opinion.

Table 9 Perception of Customers towards impact of GST on Consumptions

\begin{tabular}{|c|c|c|c|c|c|c|}
\hline Gender & Increase & Decrease & Constant & No idea & $x^{2}$ & P-Value \\
\hline Male & 61 & 38 & 101 & 18 & \multirow[t]{2}{*}{3.181} & \multirow[t]{2}{*}{0.365} \\
\hline Female & 39 & 41 & 89 & 14 & & \\
\hline \multicolumn{7}{|l|}{ Age group } \\
\hline $18-30$ & 89 & 68 & 176 & 28 & \multirow[t]{4}{*}{15.784} & \multirow[t]{4}{*}{0.072} \\
\hline $31-45$ & 7 & 11 & 12 & 3 & & \\
\hline $46-60$ & 1 & 0 & 2 & 1 & & \\
\hline $61 \&$ above & 3 & 0 & 0 & 0 & & \\
\hline \multicolumn{7}{|l|}{ Educational Qualification } \\
\hline up to 10 th & 1 & 0 & 0 & 1 & \multirow[t]{3}{*}{11.900} & \multirow[t]{3}{*}{0.064} \\
\hline 10th to graduation & 65 & 46 & 115 & 65 & & \\
\hline above graduation & 34 & 33 & 75 & 34 & & \\
\hline \multicolumn{7}{|l|}{ Profession } \\
\hline House wife & 1 & 1 & 2 & 1 & \multirow[t]{5}{*}{41.826} & \multirow[t]{5}{*}{0.000} \\
\hline Student & 73 & 62 & 143 & 73 & & \\
\hline Service holder & 10 & 13 & 26 & 10 & & \\
\hline Self employed / business & 4 & 0 & 8 & 4 & & \\
\hline Profession & 12 & 3 & 11 & 12 & & \\
\hline \multicolumn{7}{|l|}{ Geographical Location } \\
\hline Cuttack / Bhubaneswar & 56 & 44 & 104 & 56 & \multirow[t]{4}{*}{5.014} & \multirow[t]{4}{*}{0.833} \\
\hline Berhampur & 6 & 4 & 9 & 6 & & \\
\hline Sambalpur & 4 & 5 & 6 & 4 & & \\
\hline Othertdid & 34 & 26 & 71 & 34 & & \\
\hline \multicolumn{7}{|l|}{ Type of Customer } \\
\hline Retail & 68 & 48 & 148 & 26 & \multirow[t]{2}{*}{10.431} & \multirow[t]{2}{*}{0.015} \\
\hline Institutional & 32 & 31 & 42 & 6 & & \\
\hline
\end{tabular}

Source: Authors calculations

\section{CONCLUSION}

Goods and Services tax is no doubt a welcome step in indirect tax system of our country and it is expected to provide a positive outcome to our economy. Though it is almost forty since its implementation, our economy is still awaiting to get the maximum benefits of this tax reforms. The present global covid-19 pandemic during last ten months have been the obstacle in our economic development. So far awareness and perception towards this new tax is concerned, the customers, being one of the most important stakeholders this system have changed a lot as compared to those initial months of its implementation. Form our study, it is 
clear that more than $95 \%$ of customers are at least know something about GST and news and electronic means play an important role in this regard. Further, customers education, profession and place play a dominant role in deciding the perception of customers towards prices, expenditure and consumptions after implementation of GST.

\section{ACKNOWLEDGEMENT}

The authors would like to thank Odisha State Higher Education Council, Department of Higher Education and Government of Odisha for OURIIP seed fund research support.

\section{REFERENCES}

[1] Antony, J., \& Johan, R. (2020). An evaluation of retailers Anagamaly Under GST regime. Dhan - Path '20 (pp76-81). Kerala, India: NIMITP.

[2] Beri, Y. (2017). Goods and Services Tax (GST) -A global scenario. International Journal of Social Science and Interdisciplinary Research (IJSSIR), 6(1), 1-9.

[3] Carvalho, E., \& Lian, Z. (2010). The Impact of Goods and Services Tax on the Pattern of Canadian Consumer Spending and Saving. The Journal of Economic Asymmetries, 7(1), 123136. https://doi.org/10.1016/j.jeca.2010.01.007

[4] Das, A. (2017). Positive and negative impact of GST on Indian economy. International Journal of Management and Applied Science (IJMAS), 3(5), 160-162.

[5] Dhanuja, H. A., \& Venkateswaran, A. (2020). A Study on Awareness of GST among Retailers in Kanniyakumari District with Special Reference to Kalkulam Taluk. Dhan - Path '20 (pp1619). Kerala, India: NIMITP.

[6] Dilip, D., Vinoth, S., \& Jayashree, T. (2018). GST: Consumers Awareness and Adoption -A Study. International Journal of Scientific Research in Computer Science Application and Management Studies, 7(5), 1-6.

[7] Garg, M. \& Kumar, M. (2017). Indian tax structure and relevance of GST. International Journal of Advance Research and Innovative Ideas in Education, 3(4), 2199-2205.

[8] Gupta, L., \& Agarwal, A. (2018). Awareness and Understanding of GST among Indian Consumers: An Empirical Study. VISION: Journal of Indian Taxation, 4(02). https://doi.org/10.17492/vision.v4i02.11777

[9] Joy, E., Thomas, T., \& Puthussery, J. (2020). Decoding the Impact of GST Law on Share Market Operations. Dhan - Path '20 (pp7-15). Kerala, India: NIMITP.

[10] Kawale, P. S. \& Aher, Y. L. (2017). GST: An economic overview: Challenges and impact ahead. International Research Journal of Engineering and Technology (IRJET) 04(04), 27602763.

[11] Leena \& Sameena. (2017). Impact of Goods and Services Tax on Indian Economy. KAAV International of Economics, Commerce and Business Management, 4(4), 422-427.

[12] Ling, S. C., Osman, A., Muhammad, S., Yeng, S. K., \& Jin, L. Y. (2016). Goods and Services Tax (GST) Compliance among Malaysian Consumers: The Influence of Price, Government Subsidies and Income Inequality. Procedia Economics and Finance, 35, 198-205. https://doi.org/10.1016/S2212-5671(16)00025-3 
Impact of Goods and Services Tax (GST) on Customers' Perception in Odisha: An Empirical Study

[13] Mahender, P. (2017). GST effect on manufacturing industry - India. International Journal of Managerial Studies and Research (IJMSR), 5(1), 28-30.

[14] Muthupandi, S. \&, Xavier, A.J. (2017). Awareness of implementation of goods and services tax (GST) among college students' in Sivakasi. International Journal of Engineering Science and Computing, 7(4), 01-06.

[15] Nayyar, A \& Singh, I. (2018). A comprehensive analysis of Goods and Services Tax (GST) in India. Indian Journal of Finance, 12(2). 57-71.

[16] Pabreja, K. (2017). GST sentiment analysis using twitter data. International Journal of Applied Research, 3(7), 660-662.

[17] Patil, S. (2017). Myths and Reality of Goods and Services Tax (GST): A study. PRATIBHA: International Journal of Science, Spirituality, Business and Technology (IJSSBT), 5(2), 47-52.

[18] Shaari, N., Ali, A., \& Ismail, N. (2015). Student's Awareness and Knowledge on the Implementation of Goods and Services Tax (GST) in Malaysia. Procedia Economics and Finance, 31, 269-279. https://doi.org/10.1016/S2212-5671(15)01229-0

[19] Sreekumar, P. G. \& Chithra, R. (2018). A Study on the impact of GST in FMCG Sector with special reference to Palakkad District, Kerala. IOSR Journal of Business and Management (IOSR-JBM), 20(9), 53-58.

[20] Tiwari, H. \& Singh, S. N. (2018). Goods and Service Tax: Economic Revival of India. Paradigm, 22(1), 17-29.

[21] Verma, L. (2017). Impact of Goods and Services Tax (GST) on business and tax reforms in India. Journal of Business Management and Information Systems, 4(1), 15-22.

[22] Vincent, L., \& Priya, L. (2020). A Study on customer perception towards GST (Goods \&Service Tax) in Ernakulum District. Dhan - Path '20 (pp47-49). Kerala, India: NIMITP 